\title{
Genotypic Characterisation of Multi Drug Resistant Gram-Negative Bacteria with Special Reference to Carbapenem Resistance in a Teaching Hospital, Hyderabad, Telangana State
}

\author{
Swathi Gurajala ${ }^{1}$, Sandeep Kumar Tipparthi², Rajkumar H.R.V. ${ }^{3}$ \\ 1Department of Respiratory Care, College of Applied Medical Sciences, Jubail, Imam Abdul \\ Rahman Bin Faisal University, Saudi Arabia. 2,3 Department of Microbiology, Kamineni \\ Academy of Medical Sciences and Research Centre, LB Nagar, Hyderabad, Telangana, India.
}

\begin{abstract}
Bacteria develop antimicrobial drug resistance through several mechanisms, the common one being the production of enzymes. As the number of antibiotics discovered is in notable numbers in the past few years, it is important to preserve high-end antibiotics for the treatment of multidrug-resistant organisms (MDROs) infections, by appropriate use of antibiotics. A study was conducted to record prevalence, phenotypic and genotypic characters of MDROs in our hospital, with reference to carbapenem resistance. 200 multidrug-resistant clinical isolates were collected in 6 months. Carbapenem-resistant organisms were detected phenotypically confirmed for the production of carbapenemases by modified Hodge test (MHT) and genotypic detection was done by a multiplex polymerase chain reaction (PCR) assay for the five most predominant carbapenemases (bla ${ }_{N D M-1}$, bla охА-48, bla VIM, bla IMP, bla KРC). The isolates consisted of E. coli (53\%) followed by $K$. pneumoniae (30\%), P. aeruginosa (13\%), and acinetobacter spp (4\%). Among these, $40(20 \%)$ isolates were carbapenem-resistant. Of these 40, 27 (67.5\%) showed an increase in zone size by the MHT, suggestive of metallo-beta-lactamase (MBL) mediated carbapenem resistance and about $32(80 \%)$ isolates were found to contain at least one carbapenemase gene. bla NDM-1 accounted for $37.5 \%(12 / 32)$ of the isolates and was the most predominant one followed by bla оХА-48 [28 \% (9 / 32)]. 22 $\%$ (7 / 32) of the isolates had one or more carbapenemase genes. Identifying the mechanisms of resistance of pathogens is important to implement strict infection prevention and control measures in the hospital to prevent the transmission of the resistant pathogens.
\end{abstract}

\section{KEY WORDS}

Multidrug-Resistant Bacteria, Bla NDM-1 Gene, Bla oXA-48 Gene, Carbapenem Resistance, Carbapenem Resistant Organisms.

\begin{abstract}
Corresponding Author: Dr. Swathi Gurajala, Assistant Professor, Department of Respiratory Medicine, College of Applied Medical Sciences, Jubail, Imam Abdul Rahman Bin Faisal University, Kingdom of Saudi Arabia. E-mail:drswathi.gurajala@gmail.com

\section{DOI: $10.14260 / \mathrm{jemds} / 2021 / 222$}

How to Cite This Article:

Gurajala S, Tipparthi S.K, Rajkumar H.R.V. Genotypic characterisation of multi drug resistant gram-negative bacteria with special reference to carbapenem resistance in a teaching hospital, Hyderabad, Telangana state. J Evolution Med Dent Sci 2021;10(14):1039-1041, 10.14260/jemds/2021/222
\end{abstract}

Submission 20-10-2020,

Peer Review 08-02-2021,

Acceptance 15-02-2021,

Published 05-04-2021.

Copyright (c) 2021 Swathi Gurajala et al. This is an open access article distributed under Creative Commons Attribution License [Attribution 4.0 International (CC BY 4.0)] 


\section{BACKGROUND}

Antimicrobial drug resistance is an emerging public health problem of global concern. Bacteria demonstrate various resistant mechanisms to overcome the effects of the antibiotics, most common of which include antibiotic degradation by the production of enzymes. Among these, resistance to carbapenems is of particular importance as these antibiotics are life savior in a majority of hospitalised patients. Carbapenem resistance is mainly due to the production of carbapenemases, which hydrolyse the beta-lactam antibiotics like the penicillins, cephalosporins, cephamycins, and carbapenems. Verona integron Metallo-beta-lactamases types (VIM), imipenemase types (IMP), Klebsiella pneumoniae carbapenemase (KPC), oxacillinase-48 (OXA-48), and New Delhi metallo-beta-lactamase-1 (NDM-1), encoded by carbapenem resistance determining gene blavıм, blaıмр, blaкрс, blaoxA-48 and blanDM respectively are the most common types of carbapenemases. ${ }^{1}$ Resistant to carbapenems can also be due to AmpC enzymes or loss of outer membrane proteins. Several studies report about 11 - $81 \%$ prevalence of carbapenemresistant gram-negative bacteria especially Enterobacteriaceae, Pseudomonas aeruginosa and Acinetobact er baumannii. ${ }^{2-5}$

Carbapenem-resistant gram-negative bacteria (CR-GNB) have spread rapidly amongst humans. Such bacteria producing these enzymes obtain the genes by transfer of plasmids and transposons through horizontal gene transfer. ${ }^{6}$ CR-GNB also spread in hospitals through direct patient contact or from patient care equipment and the environment indirectly. In this way, the spread of these bacteria is posing danger to public health. As the number of newer antibiotics discovered in the last few years is decreasing, the carbapenem antibiotics have to be used cautiously and must be preserved. In our hospital we have observed an increased reporting of multi drug resistant organisms in the past one year. Hence, this study was conducted to determine the prevalence, phenotypic, and genotypic characterisation of multidrug-resistant gramnegative bacteria with special reference to the carbapenem resistance and characterisation of carbapenemase enzymes in our hospital.

\section{OUR STUDY}

The study was a cross-sectional study conducted in the Department of Microbiology of our teaching hospital for a period of 6 months i.e., October 2018 to March 2019. Specimens received from inpatients included endotracheal aspirates, blood, urine, sputum, and pus. 200 isolates of multidrug-resistant gram-negative bacteria (MDR GNB) were obtained during the study period. All types of non-repetitive specimens from inpatients, showing the growth of MDR GNB, resistant to carbapenems were included in the study. Repetitive isolates, isolates from patients with transfer to our hospital from other hospitals were excluded from the study. Data from eligible subjects was collected retrospectively. Patient data included antimicrobial susceptibility test results. Data was entered in WHONET 5.6 to prevent duplicate entry. The specimens received were processed by standard microbiological methods. ${ }^{7}$ All the study isolates were identified up to the species level using standard biochemical tests. $^{8}$

Antimicrobial susceptibility testing was performed by Kirby Bauer disc diffusion method as per Clinical and Laboratory Standards Institute (CLSI) guidelines. ${ }^{9}$ For Enterobacteriaceae isolates, the antibiotics tested were as follows: ampicillin $(10 \mu \mathrm{g})$, cephalexin $(30 \mu \mathrm{g})$, cefotaxime (30 $\mu \mathrm{g})$, co-trimoxazole $(1.25 / 23.75 \mu \mathrm{g})$, ciprofloxacin $(5 \mu \mathrm{g})$, gentamicin $(10 \mu \mathrm{g})$, amikacin $(30 \mu \mathrm{g})$ and piperacillintazobactam $(100 / 10 \mu \mathrm{g})$. For non-fermenters, the antibiotic panel included ceftazidime $(30 \mu \mathrm{g})$, ciprofloxacin $(5 \mu \mathrm{g})$, gentamicin $(10 \mu \mathrm{g})$, amikacin $(30 \mu \mathrm{g})$ and piperacillintazobactam (100 / $10 \mu \mathrm{g}$ ) (Hi-Media Laboratories Private Limited, Mumbai). E. coli ATCC 25922 and Pseudomonas aeruginosa ATCC 27853 were used for quality control as per the recommendations by CLSI and zones of inhibition were interpreted. Those which were resistant to three or more classes of antibiotics were designated as MDR and were further evaluated for carbapenem resistance.

The isolates resistant to carbapenems were further tested for confirmation with the Modified Hodge test as per the procedure described in the CLSI guidelines. ${ }^{9}$

The extraction of bacterial DNA was done from $18 \mathrm{hr}$ cultures by the boiling method. ${ }^{10}$ Multiplex polymerase chain reaction (PCR) assay that characterised the five most predominant carbapenemases bla $_{N D M}$, bla VIM, $_{\text {, }}$ Ia $_{I M P}$, bla $_{\text {OXA-23, }}$ blaOXA 48, and bla ${ }_{K P C}$ was performed as per established protocol using published primers. ${ }^{11,12}$ Known positive controls for each gene were used with every run. The amplicons were visualised in two percent agarose gel with staining by ethidium bromide.

200 isolates of multidrug-resistant gram-negative bacteria (MDR GNB) were obtained during the study period. Most common sample received was urine (60\%), followed by endotracheal secretions (21\%), blood (11\%) and pus (8\%). The common isolates were E. coli (48\%), K. pneumoniae (22 $\%)$, P. aeruginosa (14\%), proteus spp (6\%), citrobacter spp (2 $\%)$ and acinetobacter spp (8\%).

The isolates were least susceptible to fluoroquinolones, third generation cephalosporins; moderately susceptible to aminoglycosides, beta-lactam, and beta-lactam inhibitor combination. Overall, $20 \%$ (40 / 200) isolates were resistant to carbapenems.

The most common species isolated among MDR-GNB was E. coli $(53 \%)$ followed by K. pneumoniae $(30 \%)$ and $P$. aeruginosa (13\%) and acinetobacter spp (4\%). Of the 40 carbapenem-resistant isolates, 27 (67.5 \%) showed an increase in zone size by the MHT, suggestive of MBL mediated carbapenem resistance.

All 40 isolates were subjected to PCR and about $80 \%$ (32 / 40) isolates were found to contain at least one carbapenemase gene. The gel electrophoresis image of the products of multiplex PCR is shown in Figure 1.

The distribution of genes among the carbapenem-resistant isolates is shown in Table 1. $6.4 \%(2 / 32)$ had Class A

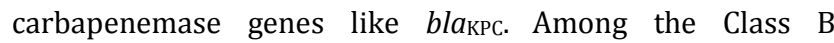
carbapenemases, bla $a_{\mathrm{NDM}-1}$ gene was found in $50 \%(16 / 32)$ whereas other genes such as bla IMP $_{1} 6.4 \%(2 / 32), b_{\text {VIM }} 9.6 \%$ (3 / 32). Among the Class D carbapenemases, bla oxa-48 gene was the most predominant and present in $28 \%(9 / 32)$. Among these, co-expression with one or more genes was noted in about $22 \%(9 / 40)$ isolates. 


\begin{tabular}{|c|c|c|c|}
\hline \multirow{2}{*}{ Organism } & \multicolumn{3}{|c|}{ Number of Carbapenem Resistant Isolates } \\
\hline & Multiplex-PCR Positive & Carbapenem Genes & Co-Expression of One or More Genes \\
\hline Escherichia coli & 17 & bla $_{N D M}-11$, bla oXA-48-7 & 6 \\
\hline Klebsiella spp & 9 & bla $_{N D M}-4$, bla $K P C-2$ & 0 \\
\hline Pseudomonas spp & 4 & bla $_{\text {VIM }}-3$, bla ${ }_{\text {IMP }}-2$ & 2 \\
\hline Acinetobacter spp & 2 & bla ${ }_{N D M}-1$, bla $_{O X A-48}-2$ & 1 \\
\hline Total & 32 & 32 & $9(22 \%)$ \\
\hline \multicolumn{4}{|c|}{ Table 1. Distribution of Genes among the Carbapenem Resistant Isolates } \\
\hline
\end{tabular}

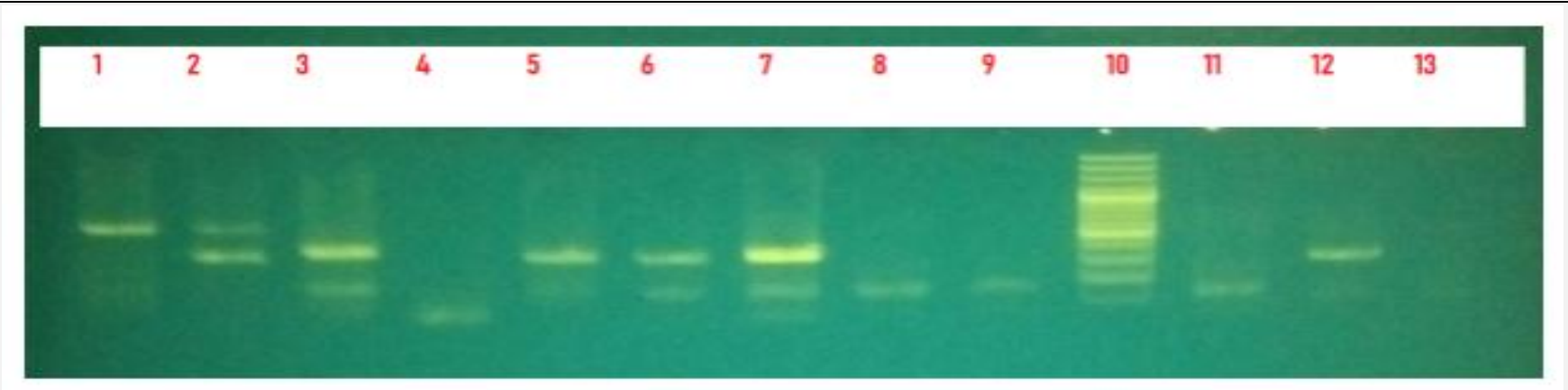

Figure 1. Gel Electrophoresis Picture Showing 100bp Ladder-Lane 10; bla NDM (439 Bp)-Lane 5, 6, 7, bla ImP (183bp)-Lane 11, bla oXA48 (736bp)-Lane 1,2

\section{CONCLUSIONS}

One of the greatest threats to public health is the antimicrobial resistance, with increasing resistance to high-end antibiotics i.e., carbapenems. This is of concern because effective and alternative drugs are not available as of now for treating the MDROs. In our study, it was concluded that multidrugresistant organisms are a very common cause of infections among hospitalised patients which may lead to an outbreak of such nosocomial infections if not detected and controlled on time. Further strict antibiotic policy and steps to minimise the irrational use of high-end antibiotics should be undertaken to minimise the emergence of these resistance mechanisms. Health care organisations should adopt mechanisms that can capture the changing trends of the prevalence of antimicrobial-resistant organisms so that the true picture is seen and national policies for containment of infection can be done.

Financial or other competing interests: None.

Disclosure forms provided by the authors are available with the full text of this article at jemds.com.

\section{REFERENCES}

[1] Mohan S, Farooq U. Prevalence and characterization of multi drug resistant gram-negative bacilli isolates from a tertiary care centre of Western U.P. India. J Pure Appl Microbiol 2019;13( 2):1069-78.

[2] Mohanty S, Gajanand M, Gaind R. Identification of carbapenemase-mediated resistance among enterobacteriaceae bloodstream isolates: a molecular study from India. Indian J Med Microbiol 2017;35( 3):421-5.
[3] Swaminathan A, Ardra M, Manoharan A, et al. Characterisation of carbapenemase producing gramnegative bacilli among clinical isolates in a tertiary care centre in Kerala, South India. Journal of the Academy of Clinical Microbiologists 2016;18( 2):100-4.

[4] Diwakar J, Verma KR, Singh PD, et al. Phenotypic detection of carbapenem resistance in gram negative bacilli from various clinical specimens of a tertiary care hospital of Western Uttar Pradesh. Int J Res Med Sci 2017;5( 8):35114.

[5] Queenan AM, Bush K. Carbapenemases: the versatile beta-lactamases. Clin Microbiol Rev 2007;20( 3):440-58.

[6] Pitout JD, Laupland KB. Extended-spectrum $\beta$-lactamaseproducing enterobacteriaceae: an emerging public-health concern. Lancet Infect Dis 2008;8( 3):159-66.

[7] Collee JG, Fraser AG, Marmion BP, et al. Mackie and McCartney practical medical microbiology. $14^{\text {th }}$ edn. New York: Churchill Livingstone 1996.

[8] McFadden JF. Biochemical tests for identification of medical bacteria. $3^{\text {rd }}$ edn. Philadelphia: Lippincott Williams and Wilkins 2000.

[9] Clinical and Laboratory Standards Institute. Performance standards for antimicrobial susceptibility testing. $28^{\text {th }}$ edn. CLSI Document M100. Wayne. PA: Clinical and Laboratory Standards Institute 2018.

[10] Alexopoulou K, Foka A, Petinaki E, et al. Comparison of two commercial methods with PCR restriction fragment length polymorphism of the tuf gene in the identification of coagulase-negative staphylococci. Lett Appl Microbiol 2006;43( 4):450-4.

[11] Poirel L, Walsh TR, Cuvillier V, et al. Multiplex PCR for detection of acquired carbapenemase genes. Diagn Microbiol Infect Dis 2011;70( 1):119-23.

[12] Ellington MJ, Kistler J, Livermore DM, et al. Multiplex PCR for rapid detection of genes encoding acquired metallobeta-lactamases. J Antimicrob Chemother 2007;59( 2):321-2. 